\title{
WAWASAN NUSANTARA SEBAGAI CARA PANDANG DAN SIKAP BANGSA INDONESIA MENGENAI DIRI SERTA LINGKUNGANNYA BERDASARKAN PANCASILA dan UUD 1945
}

Putri Devita Sari

\section{IIK STRADA INDONESIA}

novitrimaharani57@gmail.com

\begin{abstract}
Abstrak
Sebagai negara kesatuan, Republik Indonesia adalah sebuah negara kepulauan yang berciri Nusantara. Hal tersebut sesuai dengan pasal 25A UUD 1945 yang berbunyi bahwa “ kesatuan Republik Indonesia adalah sebuah negara kepulauan yang berciri Nusantara dengan wilayah yang batas-batas dan hak-haknya ditetapkan dengan undang-undang". Negara Indonesia adalah suatu negara kesatuan yang tidak terpecah-pecah yang dibentuk di atas dan di dalam bangsa Indonesia yang tidak terbagi-bagi. Mengingat luasnya wilayah negara Indonesia, urusan pemerintahan yang semakin kompleks, serta jumlah warga negara yang semakin banyak dan heterogen, dalam perkembangannya dilaksanakan asas otonomi dan tugas pembantuan. Pasal 18, 18A, dan 18B Undang-Undang Dasar 1945 menegaskan bahwa negara kesatuan Republik Indonesia adalah negara kesatuan dengan sistem pemerintahan daerah yang berdasarkan desentralisasi, dekonsentrasi, dan tugas pembantuan. Konsep kesatuan yang dianut di negara Indonesia meliputi aspek alamiah (konsep kewilayahan) dan aspek sosial (politik, sosial, budaya, ekonomi, serta pertahanan dan keamanan). Kesatuan wilayah meliputi darat, laut, dan udara. Kebulatan ini sesuai dengan politik kewilayahan yang dianut di negara Indonesia yaitu wawasan nusantara. Wawasan nusantara adalah cara pandang dan sikap bangsa Indonesia mengenai diri serta lingkungannya berdasarkan Pancasila dan Undang-Undang Dasar 1945. Pelaksanaan wawasan nusantara mengedepankan kesatuan wilayah dan menghargai kebinekaan untuk mencapai tujuan nasional. Perbedaan dipandang sebagai kekayaan bangsa dan wilayah Indonesia dipandang sebagai kesatuan wilayah.
\end{abstract}

Kata Kunci : Wawasan Nusantara, Politik Kewilayahan, Persatuan dan Kesatuan 


\section{Latar Belakang}

Secara konsepsional, wawasan nusantara (wawasan) merupakan wawasan nasionalnya bangsa Indonesia. Perumusan wawasan nasional bangsa Indonesia yang selanjutnya disebut wawasan nusantara, itu merupakan salah satu konsepsi politik dalam ketatanegaraan Republik Indonesia. Wawasan Nusantara sebagai wawasan nasionalnya bangsa Indonesia dibangun atas pandangan geopolitik bangsa. Pandangan bangsa Indonesia didasarkan pada konstelasi lingkungan tempat tinggalnya yang menghasilkan konsepsi wawasan nusantara. Jadi wawasan nusantara merupakan penerapan dari teori geopolitik bangsa Indonesia.

Setiap bangsa mempunyai wawasan kebangsaan yang merupakan visi bangsa yang bersangkutan menuju ke masa depan. Kehidupan berbangsa dalam suatu negara memerlukan suatu konsep cara pandangan atau wawasan kebangsaan yang bertujuan untuk menjamin kelangsungan kehidupan dan keutuhan bangsa dan wilayahnya serta jati diri bangsa itu. Bangsa yang dimaksudkan adalah bangsa yang bernegara. Perkembangan pemikiran bangsa Indonesia mengenai wawasan yang akan dianut dalam kehidupan bernegara dapat diikuti dalam sejarah pergerakan kemedekaan sejak tahun 1908, yaitu sejak kita sadar akan rasa kebangsaan. Inti dari wawasan nasional yang disebut wawasan nusantara adalah tekad untuk bersatu yang didasarkan pada cita-cita dan tujuan nasional.

Dengan demikian, wawasan nusantara berperan untuk membimbing bangsa Indonesia dalam penyelenggaraan kehidupannya serta sebagai rambu-rambu dalam perjuangan mengisi kemerdekaannya. Wawasan nusantara sebagai cara pandangan juga mengajarkan bagaimana pentingnya membina persatuan dan kesatuan dalam segenap aspek kehidupan bangsa dan negara dalam mencapai tujuan dan cita-citanya. Secara keadaanya pun, isi nilai-nilai wawasan nusantara telah tertuang dalam dasar negara yaitu Pancasila dan pembukaan UUD tahun 1945.

Dorongan yang melahirkan kebangsaan Indonesia bersumber dari perjuangan untuk mewujudkan kemerdekaan. Wawasan nusantara Indonesia menolak segala diskriminasi suku, ras, asal-usul, keturunan, warna kulit, kedaerahan, golongan, agama dan kepercayaan kepada Tuhan Yang Maha Esa, kedudukan maupun status sosial. Konsep kebangsaan kita bertujuan membangun dan mengembangkan persatuan dan kesatuan. Wawasan kebangsaan intinya adalah loyalitas warga terhadap bangsanya yang harus dipelihara secara terus menerus.

\section{Rumusan Masalah}

a. Apa saja tujuan dari politik kewilayahan yang di anut oleh bangsa Indonesia ?

b. Apa saja fungsi dari wawasan nusantara yang merupakan politik kewilayahan bangsa Indonesia?

c. Berdasarkan konsep wawasan nusantara, negara Indonesia memiliki karakteristik yang bagaimana?

\section{Tinjauan Pustaka}

Cara pandang suatu bangsa memandang tanah air beserta lingkungannya menghasilkan wawasan nasional. Wawasan nasional itu selanjutnya menjadi pandangan atau visi bangsa dalam menuju tujuannya. Namun tidak semua bangsa memiliki wawasan nasional, Inggris adalah salah satu contoh bangsa yang memiliki wawasan nasional yang 
berbunyi "Britain rules the waves". Ini berarti tanah inggris bukan hanya sebatas pulaunya, tetapi juga lautnya. Adapun bangsa Indonesia memiliki wawasan nasional yaitu wawasan nusantara.

Sebagai Wawasan nasional dari bangsa Indonesia maka wilayah Indonesia yang terdiri dari daratan, laut, dan udara diatasnya dipandang sebagai ruang hidup (lebensraum) yang satu atau utuh. Wawasan nusantara sebagai wawasan nasionalnya bangsa Indonesia dibangun atas pandangan geopolitik bangsa. Pandangan bangsa Indonesia didasarkan kepada konstelasi lingkungan tempat tinggalnya yang menghasilakan konsepsi wawasan nusantara. Jadi wawasan nusantara merupakan penerapan dari teori geopolitik bangsa Indonesia.

Wawasan nusantara berasal dari kata wawasan dan nusantara. Wawasan berasal dari kata wawas (bahasa Jawa) yang berarti pandangan, tinjauan atau penglihatan indrawi. Selanjutnya muncul kata mawas yang berarti memandang, meninjau atau melihat. Wawasan artinya pandangan, tujuan, penglihatan, tanggap indrawi. Wawasan berarti pula cara pandang, cara melihat.

Kedudukan wawasan nusantara adalah sebagai visi bangsa. Visi adalah keadaan atau rumusan umum mngenai keadaan yang dinginkan. Wawasan nasional merupakan visi bangsa yang bersangkutan dalam menuju masa depan. Visi bangsa Indonesia sesuaidengan konsep wawasan Nusantara adalah menjadi bangsa yang satu dengan wilayah yang satu dan utuh pula.

Bagi Indonesia, wawasan nusantara merupakan suatu politik kewilayahan bangsa dan negara Indonesia. Sebagai politik kewilayahan, wawasan nusantara mempunyai sifat manunggal dan utuh menyeluruh. Bersifat manunggal artinya mendorong terciptanya keserasian dan keseimbangan yang dinamis dalam segenap aspek kehidupan, baik aspek alamiah maupun aspek sosial. Adapun bersifat utuh menyeluruh artinya menjadikan wilayah nusantara dan rakyat Indonesia sebagai satu kesatuan yang utuh dan bulat serta tidak dapat dipecah-pecah oleh kekuatan apapun sesuai dengan asas satu nusa, satu bangsa, dan satu bahasa persatuan Indonesia. Dengan wawasan nusantara, kedudukan manusia Indonesia ditempatkan dalam kerangka kesatuan politik, sosial budaya, ekonomi, serta pertahanan dan keamanan. Manusia Indonesia merasa satu, senasib sepenanggungan, sebangsa dan setanah air, serta mempunyai satu tekad dalam mencapai cita-cita pembangunan nasional.

Kelangsungan hidup bangsa dan negara yang bermartabat dengan mewujudkan cita-cita dan tujuan nasional. Pemahaman dan pelaksanaan wawasan nusantara yang lebih baik dalam ranah kehidupan pribadi maupun kolektif serta dalam wilayah publik sangat menentukan kelangsungan hidup bangsa dan negara. Dibutuhkan kesadaran warga negara dan penyelanggara negara yang memadai di dalam melaksanakan kewajiban dan tanggung jawab. Di tengah tekanan berbagai masalah yang menghimpit bangsa.

\section{Pembahasan}

a. Wawasan nusantara bertujuan mewujudkan nasionalisme yang tinggi di segala aspek kehidupan rakyat Indonesia yang lebih mengutamakan kepentingan nasional daripada kepentingan individu, kelompok, golongan, suku bangsa ataupun daerah. Hal tersebut bukan berarti menghilangkan kepentingan- 
kepentingan individu, kelompok, suku bangsa, ataupun daerah. Kepentingankepentingan tersebut tetap dihormati, diakui dan dipenuhi selama tidak bertentangan dengan kepentingan nasional atau kepentingan masyarakat banyak. Wawasann nusantara mempunyai dua tujuan yaitu sebgai berikut :

1. Tujuan nasional, yang dapat kita lihat dalam pembukaan UUD 1945 sebagai berikut :

1) Melindungi segenap bangsa Indonesia dan seluruh tumpah darah Indonesia.

2) Memajukan kesejahteraan umum.

3) Mencerdaskan kehidupan bangsa.

4) Ikut melaksanakan ketertiban dunia yang berdasarkan kemerdekaan, perdamaian abadi, dan keadilan sosial.

2. Tujuan ke dalam, yaitu mewujudkan kesatuan segenap aspek kehidupan. Oleh karena itu, dapat disimpulkan bahwa tujuan bangsa Indonesia adalah menjunjung tinggi kepentingan nasional serta kepentingan kawasan untuk menyelenggarakan dan membina kesejahteraan, kedamaian, dan Budi luhur, serta martabat manusia di seluruh dunia.

b. Wawasan nusantara berfungsi sebagai pedoman, motivasi, dorongan, serta ramburambu dalam menentukan segala kebijaksanaan, keputusan, tindakan, dan perbuatan bagi penyelenggara negara di tingkat pusat dan daerah maupun bagi seluruh rakyat Indonesia dalam kehidupan bermasyarakat, berbangsa, dan bernegara. Fungsi dari wawasan nusantara adalah sebagai berikut :

1. Wawasan nusantara berfungsi sebagai konsepsi ketahanan nasional, yaitu wawasan nusantara dijadikan konsep dalam pembangunan nasional, pertahanan keamanan, dan kewilayahan.

2. Wawasan Nusantara berfungsi sebagai wawasan pembangunan yang mencakup kesatuan politik, kesatuan ekonomi, kesatuan sosial dan politik, kesatuan sosial dan ekonomi, serta kesatuan pertahanan dan keamanan.

3. Wawasan nusantara berfungsi sebagai wawasan pertahanan dan keamanan negara, yaitu pandangan geopolitik Indonesia dalam lingkup tanah air Indonesia sebagai satu kesatuan yang meliputi seluruh wilayah dan segenap kekuatan negara.

4. Wawasan nusantara berfungsi sebagai wawasan kewilayahan. Dalam hal ini wawasan nusantara berfungsi dalam pembatasan negara supaya tidak terjadi sengketa antar negara.

c. Karakteristik negara Indonesia berdasarkan konsep wawasan nusantara :

1. Negara kepulauan yang pengertiannya adalah suatu wilayah lautan yang dikelilingi pulau-pulau besar dan kecil.

2. Konsep utamanya adalah manunggalnya wilayah laut, darat, dengan wilayah udara.

3. Laut atau perairan merupakan wilayah pokok, bukan merupakan pelengkap. 
4. Laut merupakan bagian yang tidak terpisahkan dari daratan, bukan pemisah antara daratan dan pulau yang satu dengan yang lainnya. 


\section{Kesimpulan}

Wawasan Nusantara adalah pandangan untuk menjadi bangsa yang satu dan utuh dalam satu kesatuan republik Indonesia. Untuk mencapai tujuan nasional maka diperlukan suatu paham geopolitik dan dikembangkan menjadi wawasan nusantara serta diwujudkan sebagai satu kesatuan politik, ekonomi, sosial budaya, pertahanan keamanan. Kesatuan wawasan nusantara ini dilakukan dengan cara desentralisasi dalam penyelenggaraan pemerintahan. 


\section{Daftar Pustaka}

Budiman, A., Nurholis, E., \& Erlina, T. (2020). PELATIHAN WAWASAN KEBANGSAAN BAGI PERTAHANAN SIPIL (HANSIP) DI DESA KERTAHAYU KECAMATAN PAMARICAN KABUPATEN CIAMIS. Abdimas Galuh, 2(2), 181-185.

itu Geopolitik, A. Wawasan Nusantara Sebagai Geopolitik Indonesia.

SARI, P. D. (2021). Memperkukuh Persatuan dan Kesatuan Bangsa dalam Negara Kesatuan Republik Indonesia.

SARI, P. D. (2021). Penerapan Konsep Hak Dan Kewajiban Peserta BPJS Dalam Memperoleh Jaminan Kesehatan.

SARI, P. D. (2021). Dinamika Demokrasi yang pernah dianut di Negara Indonesia.

Sodik, M. A., Suprapto, S. I., \& Pangesti, D. (2013). Faktor-Faktor Yang Berhubungan Dengan Pelaksanaan Pelayanan Prima Pegawai Di Rsui Orpeha Tulungagung. STRADA Jurnal Ilmiah Kesehatan, 2(1), 24-32.

Siyoto, S., \& Sodik, M. A. (2015). Dasar metodologi penelitian. Literasi Media Publishing.

Oktoriani, E. N., Sutrisno, J., Mayasari, E., \& Sodik, M. A. (2018). Analysis of medical record complete flexibility to complete claims of health BPJS RS Baptis Kota Batu. Journal of Global Research in Public Health, 3(1), 46-53.

Sodik, M. A. (2016). Leprosy Patients in public perception: A qualitative study of patient confidence (dis) in the Community. J Global Res Public Health, 1(2), 99-106.

Attoriq, S., \& Sodik, M. A. (2018). Pencegahan Dan Pengendalian Infeksi Terkait Pelayanan Kesehatan Di Lahan Praktik.

Tule, A. R., Siyoto, S., Dwianggimawati, M. S., \& Sodik, M. A. (2018). The Analysis Factors Affecting Interest In Medication Of Receipt Help Aid Bpjs Participant In Balowerti Public Health Center Kediri City. Journal of Global Research in Public Health, 3(1), 68-75.

Sodik, M. A., \& Nzilibili, S. M. M. (2017). The Role Of Health Promotion And Family Support With Attitude Of Couples Childbearing Age In Following Family Planning Program In Health. Journal of Global Research in Public Health, 2(2), 82-89.

Riyani, A., \& Hidajaturrokhmah, N. Y. (2019). Effevtiveness Health Education Using Audio Visual With Lectures And Poster With Lectures Of Changes In Behavior Selection Of Snacks In Tulungagung Elementary School. Journal of Global Research in Public Health, 4(2), 145-152.

Sodik, M. A. (2018, September). Analysis of Improved Attitude of Youth in HIV/AIDS Prevention through the Provision of Health Education with Peer Education. In The 2nd Joint International Conferences (Vol. 2, No. 2, pp. 495-502).

Sodik, M. A., Yudhana, A., \& Dwianggimawati, M. S. (2018). Nutritional status and anemia in islamic boarding school adolescent in Kediri City East Java Indonesia. Indonesian Journal of Nutritional Epidemiology and Reproductive, 1(3), 172-176. 
Buku :

Pendidikan Pancasila dan Kewarganegaraan. Memperkukuh Persatuan dan Kesatuan Bangsa dalam Negara Kesatuan Republik Indonesia. Viva Pakarindo. Klaten, Jawa Tengah. 